\title{
Advances in pain management for older patients with cancer
}

\author{
Georges El Hachem ${ }^{1 *}$, Francisco Oliveira Rocha ${ }^{2 *}$, Thierry Pepersack ${ }^{2}$, Youssef Jounblat ${ }^{3}$, Annie Drowart ${ }^{2}$ and Lissandra Dal Lago $^{2}$ \\ ${ }^{1}$ Department of Hematology and Medical Oncology, Saint George Hospital University Medical Center, University of Balamand, PO Box 166378, Ashrafieh, \\ Beirut 1100 2807, Lebanon \\ ${ }^{2}$ Medical Oncology Department, Institut Jules Bordet, L'Université Libre de Bruxelles (U.L.B), Brussels, Belgium \\ ${ }^{3}$ Department of Hematology and Medical Oncology, Lebanese University, PO Box 6573/14, Badaro, Museum, Beirut, Lebanon \\ ${ }^{*}$ Georges El Hachem and Francisco Oliveira Rocha contributed equally to writing this article.
}

\begin{abstract}
The population of older patients is growing with a rising prevalence of cancer diagnoses and cancer-related pain syndromes. Older patients are also vulnerable to misleading pain evaluations and under treatment with opioids. Barriers to the effective and safe management of analgesics include pain assessments and the complex management of the best analgesic choice and dose-titration while achieving the fewest side effects. In this review, we will provide an overview of the challenges present in assessment and treatment choices, along with practical tips for routine clinical practice.
\end{abstract}

Keywords: Geriatric patients, cancer, pain assessment, pain management

\section{Introduction}

Cancer risk increases with age, and a rapidly growing older population will increase the demand for cancer care. The diagnosis and treatment of cancer and cancer-related symptoms in older age groups are often complicated by other medical conditions. Despite therapeutic advances in analgesia, cancer-related pain remains an important and often unresolved problem [1]. At least $50 \%$ of cancer patients present with pain, with one-third being graded as moderate to severe. The highest prevalence of pain concerns is within the metastatic setting, where the goal of any cancer treatment is palliative [2].

Nowadays, geriatric oncology has become an independent speciality that deals with a population that is quite different from the patients included in most published clinical trials. Currently, information on the particular management of cancer-associated pain has to be extrapolated from younger patients [3]. There is a lack of randomised clinical trials studying cancer-related pain management, which have been performed exclusively in older adults [4]. In nursing home residents, 7 out of 10 geriatric patients are burdened with non-oncologic pain [5]. In the geriatric frail population, there is a high prevalence of cognitive impairment, multiple comorbidities and malnutrition and potentially inappropriate medications that may challenge pain management [6].

This article provides an overview on the specific aspects of pain assessment and management in geriatric oncology patients, with special attention paid to analgesic choices and drug interactions.
Correspondence to: Lissandra Dal Lago Email: lissandra.dallago@bordet.be

ecancer $2019,13: 980$

https://doi.org/10.3332/ecancer.2019.980

Published: 03/12/2019

Received: 29/07/2019

Publication costs for this article were supported by ecancer (UK Charity number 1176307).

Copyright: (c) the authors; licensee ecancermedicalscience. This is an Open Access article distributed under the terms of the Creative Commons Attribution License (http:// creativecommons.org/licenses/by/3.0), which permits unrestricted use, distribution, and reproduction in any medium, provided the original work is properly cited. 


\section{Geriatric oncology specificity}

The amplitude of pain and the way it affects frail older adults with cancer is substantial. Ageing leads to an alteration in the pharmacokinetic and pharmacodynamic profiles, including a narrow therapeutic index [7], delayed drug elimination due to hepatic and renal insufficiency and reduced receptor sites for drug binding and reduced volume of distribution [8,9]. Although geriatric oncology patients have the particularity of a different physiological reserve and usually more comorbidities, they share the same cancer-related symptoms as the younger population.

Frail older patients might express their symptoms in different ways when compared to younger ones [10]. Cataldo et al [11] demonstrated in a cross-sectional study that older patients reported significantly fewer pain symptoms than their younger counterparts. Nipp et al [4] performed a secondary data analysis from a randomised two-by-two factorial trial in order to determine whether pain medications used in older patients were associated with better pain control. The population consisted of frail individuals aged 65 or older who were randomised to receive care in a geriatric inpatient unit, outpatient clinic, both or neither. Ninety-nine individuals with cancer were included, of whom 44 received a geriatric evaluation and were treated in a management unit care (GEMU) and 55 were treated with standard care procedures. GEMU patients (from inpatient or outpatient clinics) had a higher number of interventions as compared with those in usual care, mainly in the form of psychiatry, endocrinology, psychology and occupational and physical therapy. Besides there being no significant difference in the pain medication used between the intervention and usual care groups, there was significantly better pain control in the individuals of the GEMUs, suggesting that this might be related to an interdisciplinary approach [4].

In dementia, changes to pain perception and processing appear to vary in direction and quality depending on the type of neuropathology, pain and the severity of dementia [12]. Studies to date have indicated that pain is no less frequent or intense when experienced by these patients, despite changes in their ability to communicate [12]. Current evidence also suggests that pain perception and pain processing are not reduced in Alzheimer's disease [13], as it does not necessarily affect the somatosensory cortex where the brain perceives stimuli to be painful [7].

From this perspective, palliative care specialists and medical oncologists should be aware of certain geriatric specificities in order to adapt pain cancer evaluation and management. It has been demonstrated that geriatric patients accept pain as an inevitable part of cancer [14] and often report concerns about pain treatments and side effects. Physicians usually prescribe analgesics differently for this population, as they tend to care more about side effects. However, it has been demonstrated that uncontrolled pain might worsen a patient's frailty and participates in the deterioration of the performance status and quality of life of geriatric oncology patients [15].

\section{Pain assessment in the geriatric population}

The complexity of cancer-related pain and its symptoms affect many aspects of a geriatric patient's life and proxies. Pain can heavily affect their levels of physical activity, social interactions, sexuality and emotional and psychological status' [16]. A thorough anamnesis, including details of the underlying malignant disease and received treatments as well as the impact of pain on their quality of life should be taken [17]. Patients in remission for cancer may also still have pain, such as phantom pain, pain from irradiated sites and chemotherapy or surgeryrelated neuropathy [18].

Pain assessments can be very challenging in the presence of cognitive impairment, behavioural changes and communication barriers, where a standard simple verbal rating scale and visual analogue scale may not be useful [19, 20-22]. Indeed, older patients tend to hide symptoms of pain and avoid expressing the need for relief. Some patients might believe that pain reflects the severity of a cancerous disease. Others are afraid of being a source of bother to their families or healthcare providers, while some think that the side effects of analgesics might worsen their medical condition [19]. While assessing pain in the older population, clinicians should also assess their concurrent comorbidities. Furthermore, the ability to perceive pain due to age-related loss of sensory neurons might also affect pain assessments in older age groups [8, 23].

The self-reporting of pain is often unattainable in geriatric patients with cognitive impairment due to difficulties in the comprehension of commonly used pain assessment tools [24-28]. Lukas et al [25] found that while a numerical rating scale could be used by $75 \%$ of older adults with mild cognitive impairment, only $57 \%$ of patients with moderate impairment and none of the severely impaired patients could utilise the tool. Despite a considerable number of pain assessment tools being available for use in the older, cognitively impaired population, there is limited evidence regarding their reliability, validity and clinical utility [29]. In patients with cognitive impairment, acute and breakthrough 
pain are usually associated with grimacing and sympathetic hyperactivity, such as tachycardia, tachypnoea, hypertension and diaphoresis, whereas such findings are often absent in chronic pain. The latter is usually associated with vegetative signs, including lassitude, sleep disturbance and anorexia (see Table 1). Careful monitoring of such manifestations might be very helpful in pain detection and assessment [30]. Also, the assessment of discomfort in dementia protocol can be very helpful in such situations. It is based on the assumption that behaviours associated with dementia are symptoms of unmet physiologic and/or non-physiologic needs. It takes into consideration the behavioural symptoms that are mentioned in Table 1, along with a careful assessment of the vital signs and a review of systems with a physical examination [31]. The checklist of nonverbal pain indicators (CNPI) is also based on the assessment of vocal, verbal and facial expressions, along with bracing, restless and rubbing movements at rest and upon movement. A score ranging from 0 to 10 can be calculated and used to assess the pain and response to analgesics [32,33]. Other scales based on the same principles, such as the nursing assistant-administered instrument to assess pain in demented individual (NOPPAIN), the pain assessment scale for seniors with severe dementia (PACSLAC) and the pain assessment in advanced dementia scale (PAINNAD), can also be used in the pain assessments and evaluation of this population [34].

Herr et al [35] suggested that for non-communicating patients, an empiric analgesic trial should be initiated if there are pathologic conditions or procedures that are likely to cause pain, or if pain behaviours continue after attention has been paid to basic needs and comfort measures.

They suggested an analgesic trial and titration appropriate to the estimated intensity of pain based on a patient's pathology and analgesic history be provided as follows: for mild to moderate pain, a non-opioid analgesic may be given initially (e.g., paracetamol every 4 hours for 24 hours), if behaviours improve, assume pain was the cause and continue with the analgesic adding appropriate non-pharmacologic interventions. If behaviours continue, consider giving a single low dose, short-acting opioid (e.g., hydrocodone, oxycodone or morphine) and observe the effects. If there is no change in behaviour, titrate the dose upward by $25 \%-50 \%$ and observe the effects. Continue to titrate upward until a therapeutic effect is seen, bothersome side effects occur or no benefit is determined. It may be appropriate to start the analgesic trial with an opioid for conditions in which moderate to severe pain is expected. Explore other potential causes if the behaviours continue after a reasonable analgesic trial. This analgesic titration example is conservative, and although strategies for safe titration should be followed, more aggressive approaches may be needed [36].

\section{Pain management}

Despite the fact that a substantial amount of literature has been devoted to the topic of pain in cancer patients, the management of cancer pain in the geriatric population is still extrapolated from the guidelines of younger adult patients [37].

\section{Non-pharmacological approach}

There is no validated standard non-pharmacological approach published for pain control in the cancer population [38]. Certainly, a complementary approach towards pain control in older patients requires multidisciplinary management. Among older adults with chronic non-cancer related pain, there is evidence that the addition of a non-pharmacological approach might enhance the pharmacological benefit, for example, with the use of cognitive and behavioural techniques for short-term pain relief [39]. Psychological support has been demonstrated to modify the subjective perception of the pain experience in older adults [40].

Table 1. Different signs and symptoms associated with pain in patients with cognitive impairment.

\begin{tabular}{|l|l|}
\hline Facial expressions & Frowning, grimacing, distorted expression and rapid blinking \\
\hline Verbalisations/vocalisations & Sighing, moaning, calling out, asking for help and verbal abuse \\
\hline Body movements & Rigidity, tension, guarding, increased pacing/rocking, inactivity or motor restlessness \\
\hline Changes in interpersonal interactions & Aggressive, resisting care, disruptive and withdrawn \\
\hline Mental status change & Crying, sadness, increased confusion, irritability and distress \\
\hline Physiological changes & Tachycardia, tachypnea, hypertension and diaphoresis and pupil dilatation \\
\hline
\end{tabular}


Depression is highly prevalent in cancer, and especially among people with chronic pain [41, 42]. It is underreported in older patients where it should always be suspected and managed adequately [43].

Despite being less studied in older populations, palliative antalgic radiation therapy is being used as an efficient treatment for pain control. However, it must be considered that palliative radiation therapy, even with limited fields, can be associated with higher rates of myelotoxicity in the geriatric population, as they dispose of a lower bone marrow reserve as compared with younger populations [44, 45].

\section{Pharmacological management}

Unfortunately, numerous studies have documented that older patients are often undertreated for pain, with patterns including lower doses of analgesics and the use of only non-opioid pain-reliefs [46]. Guidelines from the National Comprehensive Cancer Network (NCCN), European Society of Medical Oncology (ESMO) [3] and the American Geriatric Society (AGS) recommend the use of the WHO sequential threestep analgesic ladder from non-opioids to weak opioids to strong opioids [47]. This is the same pharmacologic approach as for younger adults, but with the direction to 'start low and go slow' as the general rule of opioid titration. This strategy helps to compensate for possible concerns such as diminished drug metabolism and careful titration to effect $[48,49]$. No research confirms that weight should be used in determining the starting dose $[50,51]$.

\section{Non-opioids, adjuvants and bone antiresorptive therapies}

Paracetamol is the first current option associated with less side effects in older adults, provided that maximal dose is respected. However, it is rarely sufficient for the control of cancer-related pain as monotherapy, but can be associated with adjuvant treatments [52].

According to Cochrane Systematic Reviews [53], there is no enough evidence to support the use of oral non-steroidal anti-inflammatory drugs (NSAIDs) alone or in combination with another ladder of opioid medications to relieve cancer-related pain in adults. Furthermore, NSAIDs can more frequently result in undesirable side effects in older patients, mainly in the form of peptic ulcer disease and renal failure, and therefore, NSAIDS are considered an inappropriate prescription for this population [54].

Adjuvant treatments might diminish opioid requirements by increasing the efficacy of other analgesics and be more effective for specific pain, such as neuropathic pain.

Glucocorticoids are the most potent anti-inflammatory drug and are able to reduce cancer pain by inhibiting cytokines and prostaglandin as well as reducing vascular permeability. Glucocorticoids are graded as a moderate analgesic with higher rates of toxicity, particularly over 8 weeks [55]. Nonetheless, steroids are associated with many side effects in the geriatric population, including worsening of frailty due to proximal myopathy, an increased risk of falls, osteoporosis and associated fractures, infections, aggravation of other cardiovascular-associated comorbidities, insomnia, confusion and delirium [52, 56,57]. However, they might be considered for short periods to avoid pain flares after radiotherapy and are a good option for end of life situations [58].

Antidepressants used in the treatment of chronic neuropathic pain include tricyclic antidepressants, selective serotonin reuptake inhibitors and selective noradrenaline reuptake inhibitors, all of which have increased side effects in older adults. As such, the choice should be based on the side effect profile of each drug. Tricyclic antidepressants are better avoided in this population due to anticholinergic effects and cardiac toxicity [59]. Anticonvulsants, such as pregabalin and gabapentin, have a better safety profile when used as an adjuvant treatment for persistent neuropathic pain in older adults [23].

The use of bone antiresorptive therapies, such as bisphosphonates and denosumab, is not recommended as immediate strong analgesics or to replace radiation therapy, but their addition for pain treatment is beneficial when bone pain is widespread and difficult to localise or in cases of bone pain recurrence after radiotherapy. In older patients with bone metastases that are candidates for bisphosphonates, particular attention should be paid to its potential for renal toxicity with renal monitoring. The product label advocates stepwise dose reductions when baseline creatinine clearance is $30-60 \mathrm{ml} /$ minute, and zoledronic acid is not recommended in patients with severe renal deterioration [60]. Denosumab has been demonstrated to prevent the progression of pain severity and pain interference in HrQOL in the integrated analysis of patient-reported outcomes and analgesic use from three randomised trials of denosumab and zoledronic acid [61]. 


\section{Mild opioids}

These agents are not considered the best option, as they are associated with an increased risk of confusion and alterations in the mental status of older patients. A systematic review of six observational studies demonstrated that the use of tramadol or meperidine was associated with an increased risk of delirium, whereas the use of morphine, fentanyl, oxycodone and codeine was not when compared to non-opioid medications [62].

\section{Strong opioids}

Clinician's experience, patient's previous experiences and availability of a drug from local pharmacies are determining factors in opioid selection for older adults.

Even though the use of opioid analgesics for moderate to severe pain is becoming increasingly accepted [23], published data still indicate an underuse of opioids in the older population [63-65]. This under-prescription might be explained by the potential associated side effects. Controversially, one meta-analysis has demonstrated that old age is associated with a low risk for opioids abuse and misuse [66]. Upon initiation, patients should be monitored with screening tools to assess the risk of the likelihood of opioid misuse. Such monitoring starts with opioid risk tools scores and might extend to the use of urine toxicology screens on a periodic basis [67]. Moreover, physicians should assess and guide patients and caregivers on the safe storage of the drug, given the risks for drug mixing, overdose and using opioids for a purpose other than pain reduction.

As older patients might have an increased sensitivity to opioids, drug-drug and drug-disease interactions should be monitored prior to the initiation of therapy [68]. As ageing can lead to a higher incidence of opioid-related side effects, clinicians must initiate them at the lowest possible dose and titrate upwards based on tolerability and efficacy. The presence of multiple comorbidities, polypharmacy and physiologic vulnerability can worsen adverse events where they exist $[69,70]$. It has been proposed to initiate opioids at $25 \%-50 \%$ of the adult recommended starting dose in patients older than 70 years in order to minimise side effects [71]. Chou et al [72] suggested biweekly monitoring during the initiation and dose-titration phase of treatment, and whenever the goals are not reached, the drug should be tapered and discontinued.

There is a well-established short-term efficacy for strong opioid therapy among older adults ( $\leq 12$ weeks) [73]. In a retrospective study, Reid et al [65] evaluated the opioid prescriptions for older patients suffering from chronic musculoskeletal pain. One-hundred thirty-three patients (mean age 82) were newly started on opioid therapy. This attitude led to a decrease in pain for $66 \%$ of the patients. However, opioids were discontinued in $48 \%$ of patients, mostly as a result of poorly tolerated side effects, including constipation, urinary retention, changes to mental status and nausea [65].

Previous studies have demonstrated that pharmacokinetics and pharmacodynamics depend on the glomerular filtration rate and liver excretion capacity of the patient. As the drug availability and distribution changes in older patients, the onset and duration of action can be affected. Moreover, the mu receptor concentration has not been evaluated in the geriatric population, and this may be considered to possibly affect opioid activity [74].

Morphine is the most studied opioid analgesic and must be cautiously prescribed in cases of liver and renal failure. All long-acting opioids cannot be open or crushed before oral administration. If patients are unable to swallow, fentanyl or buprenorphine transdermal patches might be a better option. Hydromorphone and methadone are usually prescribed when high doses of opioids are required, or if there is an appearance of severe side effects with morphine. The long and variable half-life observed with methadone treatment requires hospitalisation for the careful titration and monitoring of side effects, especially in the risk of respiratory depression [75, 76]. Further recommendations applicable to older patients when selecting opioids in the geriatric population are available in Table 2 [77].

The starting oral doses of opioids depends mainly on the pain intensity, patient's weight, patient's general condition and previous treatment exposure. The ESMO, ASCO and NCCN guidelines included older age in their special population categories where opioids must be prescribed with caution [3, 37, 48, 49].

Healthcare workers and patients' families must know that there is no dose limitation for opioids, with the correct dose being the dose relieving the patient's symptoms without adding side effects. When patients are receiving strong opioids without achieving the analgesic effect or 
when pain control is achieved at the expense of important side effects, it is suggested to apply the theory of 'opioid rotation'. This means that clinicians may change the opioid sub-class or keep the same molecule with a different route of administration [78, 79].

Table 3 summarises the analgesic drugs and highlights the pros and cons of each agent in the prescription for older patients with cancer.

Table 2. Opioids' safety in renal and hepatic dysfunctions.

\begin{tabular}{|l|l|l|l|l|l|}
\hline \multicolumn{2}{|l|}{ Opioids in patients with renal failure } & \multicolumn{4}{l|}{ Opioids in patients with liver failure } \\
\hline Not recommended & Use cautiously & Appears safe & Not recommended & Use cautiously & Appears safe \\
\hline Meperidine & Morphine & Fentanyl & Meperidine & Morphine & Fentanyl \\
\hline Codeine & Oxycodone & Methadone & Codeine & Oxycodone & \\
\hline Propoxyphene & & Hydromorphone & Propoxyphene & Hydromorphone & \\
\hline & & Buprenorphine & Methadone & & \\
\hline
\end{tabular}

Table 3. Drugs for cancer pain treatment in older patients.

\begin{tabular}{|c|c|c|c|c|}
\hline Drug & Geriatric considerations & Side-effects & Interactions & $\begin{array}{c}\text { Mechanism/Initial dose and } \\
\text { titration/formulations }\end{array}$ \\
\hline $\begin{array}{l}\text { Tradonal } \\
{[80,81]}\end{array}$ & $\begin{array}{l}\text { - Metabolite accumulation in } \\
\text { case of renal impairment. } \\
\text { tients at risk for seizures. } \\
\text { - Risk of respiratory depression } \\
\text { and sedation if associated with } \\
\text { other CNS depressants (like } \\
\text { benzodiazepines). }\end{array}$ & $\begin{array}{l}\text { - Increased risk of delirium } \\
\text { when compared with } \\
\text { other opioids. } \\
\text { - Risk of serotonin syn- } \\
\text { drome. } \\
\text { - Drowsiness, constipation } \\
\text { and nausea. }\end{array}$ & $\begin{array}{l}\text { - Interaction with serotonin- } \\
\text { ergic medication. }\end{array}$ & $\begin{array}{l}\text { - mu-receptor agonist. } \\
\text { - Titration: start with low dose } \\
\text { 12.5-25 mg (immediate release). } \\
\text { - Formulation: PO, IR, IV, SQ and IM. }\end{array}$ \\
\hline $\begin{array}{l}\text { Buprenorphine } \\
{[82,83]}\end{array}$ & $\begin{array}{l}\text { - Good analgesic control when } \\
\text { used as a single agent, to pre- } \\
\text { vent poly-pharmacy. } \\
\text { - Monitor closely at the starting } \\
\text { dose and titration. } \\
\text { - Can be used in case of renal } \\
\text { failure. } \\
\text { - Low addiction potential. } \\
\text { - Anti-depressive and antianxiety } \\
\text { effects. }\end{array}$ & $\begin{array}{l}\text { - Cognitive function seems } \\
\text { not affected by low TD } \\
\text { dose. } \\
\text { - Lower risk of nausea, } \\
\text { vomiting and constipa- } \\
\text { tion. } \\
\text { - Monitor for respiratory } \\
\text { depression and dizziness } \\
\text { in older patients (risk for } \\
\text { falls/fractures). } \\
\text { - TD patch: application-site } \\
\text { pruritus, hypotension. }\end{array}$ & & $\begin{array}{l}\text { - Semisynthetic opioids mu-receptor } \\
\text { agonists. } \\
\text { - TD patch: start with a } 5 \mathrm{mcg} / \text { hour } \\
\text { every } 3-4 \text { days. } \\
\text { - Formulation: IM, IV, PO, TD. }\end{array}$ \\
\hline Fentanyl [84] & $\begin{array}{l}\text { - The TD administration should } \\
\text { be avoided in cachectic cancer } \\
\text { patients. } \\
\text { - TD administration is an option } \\
\text { to oral opioid intolerance. } \\
\text { - Oral transmucosal administra- } \\
\text { tion can provide effective and } \\
\text { rapid onset of pain relief. } \\
\text { - Not recommended if severe } \\
\text { renal or hepatic impairment. }\end{array}$ & $\begin{array}{l}\text { Constipation, nausea, } \\
\text { vomiting, confusion, } \\
\text { dizziness, sedation, } \\
\text { dyspnoea and erythema } \\
\text { at application-site. } \\
\text { - Serotonin syndrome. }\end{array}$ & $\begin{array}{l}\text { - Absorption increases in } \\
\text { case of fever or cachexia/ } \\
\text { severe sarcopenia. } \\
\text { - Metabolised by the cyto- } \\
\text { chrome P450 system. }\end{array}$ & $\begin{array}{l}\text { - Synthetic opioid, mu-receptor } \\
\text { agonist. } \\
\text { - It should be avoided as a frontline } \\
\text { option in opioids-naïve patients. } \\
\text { - Initial dose is determined by } \\
\text { titration using immediate-release } \\
\text { opioid for few days. } \\
\text { - Lowest patch dose: start at } \\
12 \text { mcg/hour. } \\
\text { - Maximum effect of TD patch is } \\
\text { obtained after } 12-24 \text { hours. } \\
\text { - TD administration. } \\
\text { - Formulation: IV/TM/trans-mucosal. }\end{array}$ \\
\hline
\end{tabular}


Table 3. Drugs for cancer pain treatment in older patients. (Continued)

\begin{tabular}{|c|c|c|c|c|}
\hline $\begin{array}{l}\text { Hydromorphone } \\
{[62,74]}\end{array}$ & $\begin{array}{l}\text { - Patients who present with } \\
\text { dysphagia can benefit from the } \\
\text { liquid form, available for } \\
\text { hydromorphone, oxycodone } \\
\text { and morphine. } \\
\text { - Efficacy in patients with sleep } \\
\text { disturbance related to cancer } \\
\text { pain. } \\
\text { - Dose reduction recommended } \\
\text { in case of renal impairment. }\end{array}$ & $\begin{array}{l}\text { Decreased risk of } \\
\text { delirium compared with } \\
\text { other opioids. }\end{array}$ & $\begin{array}{l}\text { - Metabolism to apparently } \\
\text { inactive metabolites is an } \\
\text { advantage over morphine } \\
\text { in older adults with renal } \\
\text { or hepatic insufficiency. } \\
\text { - Accumulation of a neuro- } \\
\text { toxic (excitatory) metabo- } \\
\text { lite may become a concern } \\
\text { in older adults with severe } \\
\text { renal insufficiency. }\end{array}$ & $\begin{array}{l}\text { - Starting dose by } 1-2 \text { mg every } 3-4 \\
\text { hours and determine the } 24 \text {-hour } \\
\text { dose requirement after 3-7 days. } \\
\text { - Formulation: oral/IV. }\end{array}$ \\
\hline $\begin{array}{l}\text { Methadone } \\
\text { [85] }\end{array}$ & $\begin{array}{l}\text { - Lack of data about the utilisa- } \\
\text { tion of methadone in older } \\
\text { cancer population. } \\
\text { - Not recommended as a first- } \\
\text { line opioid. } \\
\text { - Can be effective in cases of } \\
\text { neuropathic pain. }\end{array}$ & $\begin{array}{l}\text { - Risk of apnoea at high } \\
\text { doses. } \\
\text { - Increased risk of cardiac } \\
\text { arrhythmias by QT inter- } \\
\text { val prolongation. } \\
\text { - Always prescribed in } \\
\text { patients who are hospi- } \\
\text { talised. }\end{array}$ & $\begin{array}{l}\text { - Metabolised by the } \\
\text { cytochrome P450 system: } \\
\text { use with caution in case of } \\
\text { poly-pharmacy. } \\
\text { - Risk of overdose (ac- } \\
\text { cumulation) during initial } \\
\text { titration. }\end{array}$ & $\begin{array}{l}\text { - Starting dose: } 1-2 \mathrm{mg} \text { q3-4 hours. } \\
\text { - Increase daily dose by } 1-2 \mathrm{mg} \text { after } \\
7 \text { or more days. } \\
\text { - Further increases in a daily dose of } \\
\text { 1-2 mg should be made no more } \\
\text { frequently than once every } 7 \text { days. } \\
\text { - Extremely long half-life. } \\
\text { - Formulation: SC/PO. }\end{array}$ \\
\hline Morphine [84] & $\begin{array}{l}\text { - Patients with lower volumes of } \\
\text { distribution can have a higher } \\
\text { peak plasma levels. } \\
\text { - Patients with renal failure might } \\
\text { have toxic reactions due to the } \\
\text { accumulation of metabolites. } \\
\text { - Increased potential risk for falls } \\
\text { and fractures. } \\
\text { - Good option for treatment } \\
\text { of neuropathic pain, with or } \\
\text { without adjuvants. }\end{array}$ & $\begin{array}{l}\text { - Side effects: nausea, } \\
\text { vomiting, respiratory } \\
\text { depression, dizziness and } \\
\text { constipation. } \\
\text { - In case of confusion, } \\
\text { vesical retention and } \\
\text { fecaloma to be excluded. }\end{array}$ & $\begin{array}{l}\text { - Metabolised in the liver. } \\
\text { - Renal excretion and } \\
\text { metabolites accumulation } \\
\text { lead to neurotoxicity. }\end{array}$ & $\begin{array}{l}\text { - Starting dose at } 50 \% \text { of the adult's } \\
\text { dose. } \\
\text { - Titration:Low dose starting: } 5 \text { mg } \\
\text { every } 4 \text { hours, steep increase by } \\
30 \%-50 \% \text { per day. } \\
\text { - Determine } 24 \text {-hour dose require- } \\
\text { ment after } 3-7 \text { days. } \\
\text { - Use of laxatives is preconised } \\
\text { - Formulations: IV/IR/PO/SC. }\end{array}$ \\
\hline $\begin{array}{l}\text { Oxycodone } \\
{[84]}\end{array}$ & $\begin{array}{l}\text { - A great choice for older } \\
\text { patients due to the absence } \\
\text { of toxic metabolites and short } \\
\text { half-lives. } \\
\text { - Low dose associated with less } \\
\text { alteration of cognitive function. } \\
\text { - Can be useful for neuropathic } \\
\text { pain treatment. }\end{array}$ & $\begin{array}{l}\text { - Like fentanyl and metha- } \\
\text { done, can be considered } \\
\text { as a less constipating } \\
\text { opioid. } \\
\text { - Headache, drowsiness, } \\
\text { dizziness, nausea and } \\
\text { vomiting. }\end{array}$ & $\begin{array}{l}\text { - No toxic metabolites. } \\
\text { - Both hepatic and renal } \\
\text { metabolism. }\end{array}$ & $\begin{array}{l}\text { - Start with } 2.5-5 \text { mg orally every } 4 \\
\text { hours as needed. } \\
\text { - After } 3-7 \text { days, determine } 24 \text {-hour } \\
\text { dose requirement. } \\
\text { - Immediate-release onset of action } \\
15 \text { minutes. } \\
\text { - Extended-release onset of action } \\
1 \text { hour. } \\
\text { - Formulation: PO. }\end{array}$ \\
\hline $\begin{array}{l}\text { Gabapentin } \\
\text { and pregabalin } \\
{[86]}\end{array}$ & $\begin{array}{l}\text { - Effective for treatment of neu- } \\
\text { ropathic pain and as adjuvant } \\
\text { treatment to other painful } \\
\text { conditions. }\end{array}$ & $\begin{array}{l}\text { - Sedation and dizziness } \\
\text { might limit the use in } \\
\text { older adults. }\end{array}$ & $\begin{array}{l}\text { Clearance highly depen- } \\
\text { dent on renal function. }\end{array}$ & $\begin{array}{l}\text { - Gabapentin: start with } 100 \text { mg/day } \\
\text { at bedtime. } \\
\text { - Pregabalin: start with } 25-50 \text { mg at } \\
\text { bedtime. } \\
\text { - Gradual titration over weeks: } \\
\text { - Formulation: PO. }\end{array}$ \\
\hline $\begin{array}{l}\text { Duloxetine and } \\
\text { venlafaxine } \\
\text { [86-88] }\end{array}$ & $\begin{array}{l}\text { Effective adjuvant in the treat- } \\
\text { ment of neuropathic pain, in- } \\
\text { cluding chemotherapy-induced. }\end{array}$ & $\begin{array}{l}\text { - Potential to cause or } \\
\text { exacerbate syndrome of } \\
\text { inappropriate antidiuretic } \\
\text { hormone secretion (SI- } \\
\text { ADH) or hyponatremia in } \\
\text { older adults. }\end{array}$ & $\begin{array}{l}\text { - To avoid in patients with } \\
\text { severe renal impairment. } \\
\text { - Fewer cardiovascular and } \\
\text { anticholinergic effects } \\
\text { than tricyclic antidepres- } \\
\text { sants. }\end{array}$ & $\begin{array}{l}\text { - Gradual titration over 2-4 weeks: } \\
\text { - Duloxetine: start with } 20-30 \mathrm{mg} / \\
\text { day. } \\
\text { - Venlafaxine: start with } 37.5 \mathrm{mg} \\
\text { orally daily. } \\
\text { - Formulation: PO. }\end{array}$ \\
\hline
\end{tabular}

Abbreviations: CNS, central nervous system; PO, per os; IR, intra-rectal; IV, intravenous; SQ, sub-cutaneous; IM, intramuscular; mg, milligram; TD, transdermal; mcg, microgram; d, day 


\section{An attempt of recommendations for geriatric patients}

- The heterogeneity of the ageing process and health status' do not allow for the deliverance of general guidelines on the management of pain in geriatrics, an individualised approach should be proposed according to the geriatric characteristics.

- Take into account the elderly persons frailty in terms of the importance of a careful and appropriate anamnesis (given the fact that complaints are sometimes not formulated, misunderstood, trivialised or in the presence of cognitive disorders).

- Consider that pain is a medical emergency since it is often accompanied by rapid functional decline and a reduction in quality of life.

- Integrate pain screening and management systematically into the comprehensive geriatric assessment.

- For non-communicating patients, an empiric analgesic trial should be initiated where there are pathologic conditions or procedures that are likely to cause pain or if pain behaviours continue after attention has been paid to basic needs and comfort measures

- Take into account the frequent presence of poly-pathology, which sometimes makes it difficult to understand the underlying problems causing the painful complaints, often requiring a targeted approach towards the identification of several potential aetiologies.

- Account for geriatric characteristics, particularly with respect to age-related pharmacokinetics and pharmacodynamics.

- Screen for potentially inappropriate prescriptions (under-, mis- and over-prescription) in general, but also for pain medication (e.g., avoid tricyclics, suppress concomitant opioid prescriptions of the second and third step, do not forget the case of prescribing drugs for neuropathic pain and recognise side effects, etc.).

\section{Conclusion}

Pain management of the geriatric population can present many challenges to clinicians. Uncontrolled pain has been associated with a poor quality of life and worse oncological outcomes. Close attention must be paid to this special population, ensuring a continuous knowledge of the high prevalence of polypharmacy, risk of drug interactions and physiological modifications affecting the analgesic's metabolism. Careful monitoring of frail patients is necessary to effectively assess and manage pain while minimising the potential for adverse events.

\section{Conflicts of interest}

The authors declare that they have no conflicts of interest.

\section{Funding statement}

All of the authors declare that they had no access to funding support for this work.

\section{Authors' contributions}

Georges El Hachem and Francisco Oliveira Rocha contributed equally to writing this article. Youssef Jounblat also contributed to writing this article. Annie Drowart, Thierry Pepersack and Lissandra Dal Lago reviewed this article and contributed to the editing of the text.

\section{References}

1. Greco MT, et al (2014) Quality of cancer pain management: an update of a systematic review of undertreatment of patients with cancer J Clin Oncol 32 4149-4154 https://doi.org/10.1200/JCO.2014.56.0383 PMID: 25403222

2. van den Beuken-van Everdingen, Hochstenbach MHJ, and Joosten LMJ, et al (2016) Update on prevalence of pain in patients with cancer: systematic review and meta-analysis J Pain Symptom Manage 51 1070.e9-1090.e9

3. Fallon M, et al (2018) Management of cancer pain in adult patients: ESMO Clinical Practice Guidelines Ann Oncol 29 iv166-iv191 https://doi.org/10.1093/annonc/mdy152 PMID: 30052758 
4. Nipp R, Sloane R, and Rao AV, et al (2012) Role of pain medications, consultants, and other services in improved pain control of elderly adults with cancer in geriatric evaluation and management units J Am Geriatr Soc 60 1912-1917 https://doi.org/10.1111/j.15325415.2012.04143.x PMID: 23036028 PMCID: 3645305

5. Ferrell BA, Ferrell BR, and Osterweil D (1990) Pain in the nursing home J Am Geriatr Soc 38 409-414 https://doi.org/10.1111/ j.15325415.1990.tb03538.x PMID: 2109765

6. Deliens $C$ et al (2016) Drugs prescribed for patients hospitalized in a geriatric oncology unit: Potentially inappropriate medications and impact of a clinical pharmacist J Geriatr Oncol 7 463-470 https://doi.org/10.1016/j.jgo.2016.05.001 PMID: 27238734

7. Bjoro K and Herr K (2008) Assessment of pain in the nonverbal or cognitively impaired older adult Clin Geriatr Med 24 237-262 https:// doi.org/10.1016/j.cger.2007.12.001 PMID: 18387454

8. Davis MP and Srivastava M (2003) Demographics, assessment and management of pain in the elderly Drugs Aging 20 23-57 https://doi. org/10.2165/00002512-200320010-00003 PMID: 12513114

9. Opioids in patients with renal or hepatic dysfunction [https://www.practicalpainmanagement.com/treatments/pharmacological/opioids/opioids-patients-renal-hepatic-dysfunction] Date accessed: 04/10/18

10. Yamanashi $\mathrm{H}$ et al (2016) Multiple somatic symptoms and frailty: cross-sectional study in Japanese community-dwelling elderly people Fam Pract 33 453-460 https://doi.org/10.1093/fampra/cmw028 PMID: 27130337

11. Cataldo JK, et al (2013) Differences in the symptom experience of older versus younger oncology outpatients: a cross-sectional study BMC Cancer 13 https://doi.org/10.1186/1471-2407-13-6 PMID: 23281602 PMCID: 3576303

12. Scherder E, et al (2009) Pain in dementia Pain 145276 https://doi.org/10.1016/j.pain.2009.04.007 PMID: 19409705

13. Cole LJ, et al (2006) Pain sensitivity and fMRI pain-related brain activity in Alzheimer's disease Brain 129 2957-2965 https://doi. org/10.1093/brain/awl228 PMID: 16951408

14. Gagliese L, et al (2009) Age-related patterns in adaptation to cancer pain: a mixed-method study Pain Med $101050-1061$ https://doi. org/10.1111/j.1526-4637.2009.00649.x PMID: 19594849

15. Reid MC, Eccleston C, and Pillemer K (2015) Management of chronic pain in older adults BMJ $350 \mathrm{~h} 532 \mathrm{https://doi.org/10.1136/bmj.}$ h532 PMID: 25680884 PMCID: 4707527

16. Dahl JL (1996) Effective pain management in terminal care Clin Geriatr Med 12 279-300 https://doi.org/10.1016/S07490690(18)30227-1 PMID: 8799348

17. Megari K (2013) Quality of life in chronic disease patients Health Psychol Res 1 https://doi.org/10.4081/hpr.2013.932 PMID: 26973912 PMCID: 4768563

18. BrownMR,RamirezJD,andFarquhar-Smith(2014)PainincancersurvivorsBrJPain8139-153https://doi.org/10.1177/2049463714542605

19. Pain: Current understanding of assessment, management, and treatments 101

20. Daut RL, Cleeland CS, and Flanery RC (1983) Development of the Wisconsin Brief Pain Questionnaire to assess pain in cancer and other diseases Pain 17 197-210 https://doi.org/10.1016/0304-3959(83)90143-4 PMID: 6646795

21. Fishman B, et al (1987) The memorial pain assessment card. A valid instrument for the evaluation of cancer pain Cancer $601151-1158$ PMID: 3300951

22. Melzack R (1975) The McGill Pain Questionnaire: Major properties and scoring methods Pain 1 277-299 https://doi.org/10.1016/03043959(75)90044-5 PMID: 1235985

23. (2009) American Geriatrics Society Panel on pharmacological management of persistent pain in older persons. Pharmacological management of persistent pain in older persons J Am Geriatr Soc 57 1331-1346 https://doi.org/10.1111/j.1532-5415.2009.02376.x

24. Brummel-Smith K et al (2002) Outcomes of pain in frail older adults with dementia J Am Geriatr Soc 50 1847-1851 https://doi. org/10.1046/j.1532-5415.2002.50514.x 
25. Lukas A, Niederecker T, and Günther I, et al (2013) Self- and proxy report for the assessment of pain in patients with and without cognitive impairment Z Für Gerontol Geriatr 46 214-221 https://doi.org/10.1007/s00391-013-0475-y

26. Scherder EJA and Bouma A (2000) Visual analogue scales for pain assessment in Alzheimer's disease Gerontol 46 47-53 https://doi. org/10.1159/000022133

27. Binnekade T, et al (2017) Pain experience in dementia subtypes: A systematic review [https://www.ingentaconnect.com/contentone/ ben/car/2017/00000014/00000005/art00003] Date accessed: 22/11/18

28. Wynne CF, Ling SM, and Remsburg R (2000) Comparison of pain assessment instruments in cognitively intact and cognitively impaired nursing home residents Geriatr Nur (Lond) 21 20-23 https://doi.org/10.1067/mgn.2000.105793

29. Lichtner $\mathrm{V}$, et al (2014) Pain assessment for people with dementia: a systematic review of systematic reviews of pain assessment tools BMC Geriatr 14138 https://doi.org/10.1186/1471-2318-14-138 PMID: 25519741 PMCID: 4289543

30. Snow AL and Shuster JL (2006) Assessment and treatment of persistent pain in persons with cognitive and communicative impairment J Clin Psychol 62 1379-1387 https://doi.org/10.1002/jclp.20317 PMID: 16937350

31. Kovach CR, Noonan PE, and Griffie J, et al (2002) The assessment of discomfort in dementia protocol Pain Manag Nurs 3 16-27 https:// doi.org/10.1053/jpmn.2002.30389 PMID: 11893998

32. Feldt KS (2000) The checklist of nonverbal pain indicators (CNPI) Pain Manag Nurs 1 13-21 https://doi.org/10.1053/jpmn.2000.5831

33. Nygaard HA and Jarland M (2006) The checklist of nonverbal pain indicators (CNPI): testing of reliability and validity in Norwegian nursing homes Age Ageing 35 79-81 https://doi.org/10.1093/ageing/afj008

34. Wheeler MS (2006) Pain assessment and management in the patient with mild to moderate cognitive impairment Home Healthc Now 24354 https://doi.org/10.1097/00004045-200606000-00003

35. Pain assessment in the nonverbal patient: position statement with clinical practice recommendations [https://www.ncbi.nlm.nih.gov/ pubmed/16730317] Date accessed: 09/10/19

36. Gordon DB, et al (2004) The use of 'as-needed' range orders for opioid analgesics in the management of acute pain: a consensus statement of the American Society for Pain Management Nursing and the American Pain Society Pain Manag Nurs Off J Am Soc Pain Manag Nurses 5 53-58

37. Paice JA and Ferrell B (2011) The management of cancer pain CA Cancer J Clin 61 157-182 https://doi.org/10.3322/caac.20112 PMID: 21543825

38. Hökkä M, Kaakinen P, and Pölkki TA (2014) Systematic review: non-pharmacological interventions in treating pain in patients with advanced cancer J Adv Nurs 70 1954-1969 https://doi.org/10.1111/jan.12424

39. Morone NE, Greco CM, andWeiner DK (2008) Mindfulness meditation for the treatment of chronic low back pain in older adults: A randomized controlled pilot study Pain 134 310-319 https://doi.org/10.1016/j.pain.2007.04.038

40. Jones MR, et al (2016) Pain in the elderly Curr Pain Headache Rep 20 https://doi.org/10.1007/s11916-016-0551-2

41. Chronic pain-associated depression: antecedent or consequen Clin J Pain [https://journals.Iww.com/clinicalpain/Abstract/1997/06000/ Chronic_Pain_Associated_Depression___Antecedent_or.6.aspx] Date accessed: 04/04/19

42. Hotopf M, Chidgey J, and Addington-Hall J, et al (2002) Depression in advanced disease: a systematic review Part 1 Prevalence and case finding Palliat Med 16 81-97 https://doi.org/10.1191/02169216302pm507oa PMID: 11969152

43. Schroevers MJ, Ranchor AV, and Sanderman R (2004) The role of age at the onset of cancer in relation to survivors' long-term adjustment: A controlled comparison over an eight-year period J Psycho Oncol 13 740-752 https://doi.org/10.1002/pon.780

44. Feuvret L, Cuenca X, and Lavaud P, et al (2013) Pain management in radiation oncology Cancer Radiother J Soc Francaise Radiother Oncol 17 523-527 
45. Zeng L, et al (2012) Quality of life after palliative radiation therapy for patients with painful bone metastases: results of an international study validating the EORTC QLQ-BM22 Int J Radiat Oncol Biol Phys 84 e337-342 https://doi.org/10.1016/j.jirobp.2012.05.028 PMID: 22763028

46. National Academies of Sciences (2017) Pain management and the intersection of pain and opioid use disorder National Academies Press (US)

47. World Health Organization (1996) Cancer pain relief: with a guide to opioid availability

48. Atkinson TJ, Fudin J, and Pandula A, et al (2013) Medication pain management in the elderly: unique and underutilized analgesic treatment options Clin Ther 35 1669-1689 https://doi.org/10.1016/j.clinthera.2013.09.008 PMID: 24161287

49. Swarm RA, Janjan NA, and Putnam A (2016) NCCN Guidelines Index Adult Cancer Pain TOC Discussion 91

50. Macintyre PE and Jarvis DA (1996) Age is the best predictor of postoperative morphine requirements Pain 64 357-364 https://doi. org/10.1016/0304-3959(95)00128-X PMID: 8740614

51. Burns JW, et al (1989) The influence of patient characteristics on the requirements for postoperative analgesia. A reassessment using patient-controlled analgesia Anaesthesia 44 2-6 https://doi.org/10.1111/j.1365-2044.1989.tb11086.x PMID: 2929902

52. Lussier D, Huskey AG, and Portenoy RK (2004) Adjuvant analgesics in cancer pain management The Oncologist 9 571-591 https://doi. org/10.1634/theoncologist.9-5-571 PMID: 15477643

53. Derry S, et al (2017) Oral nonsteroidal anti-inflammatory drugs (NSAIDs) for cancer pain in adults Cochrane Database Syst Rev https:// doi.org/10.1002/14651858.CD012638

54. Lucchetti, G and Lucchetti ALG (2017) Inappropriate prescribing in older persons: A systematic review of medications available in different criteria Arch Gerontol Geriatr 68 55-61 https://doi.org/10.1016/j.archger.2016.09.003

55. Paulsen $\varnothing$, Aass N, and Kaasa S (2013) Do corticosteroids provide analgesic effects in cancer patients? A systematic literature review J Pain Symptom Manage 46 96-105 https://doi.org/10.1016/j.jpainsymman.2012.06.019

56. Hardy JR, et al (2001) A prospective survey of the use of dexamethasone on a palliative care unit Palliat Med 15 3-8 https://doi. org/10.1191/026921601673324846 PMID: 11212465

57. Sturdza A, et al (2008) The use and toxicity of steroids in the management of patients with brain metastases Support Care Cancer 16 1041-1048 https://doi.org/10.1007/s00520-007-0395-8 PMID: 18256860

58. Lim FMY, Bobrowski A, and Agarwal A, et al (2017) Use of corticosteroids for pain control in cancer patients with bone metastases: a comprehensive literature review Curr Opin Support Palliat Care 1178 https://doi.org/10.1097/SPC.0000000000000263 PMID: 28306570

59. American Geriatrics Society 2015 updated Beers Criteria for potentially inappropriate medication use in older adults Clinical Practice Guidelines Guideline Central [https://www.guidelinecentral.com/summaries/american-geriatrics-society-2015-updated-beers-criteriafor-potentially-inappropriate-medication-use-in-older-adults/] Date accessed: 04/03/19

60. Coleman R, Body JJ, and Aapro M, et al (2014) Bone health in cancer patients: ESMO Clinical Practice Guidelines Ann Oncol 25 iii124iii137 https://doi.org/10.1093/annonc/mdu103 PMID: 24782453

61. Pain and health-related quality of life in patients with advanced solid tumours and bone metastases: integrated results from three randomized, double-blind studies of denosumab and zoledronic acid Springer [https://link.springer.com/article/10.1007/s00520-0131932-2] Date accessed: 04/03/19

62. Swart LM, van der Zanden V, and Spies, et al (2017) The comparative risk of delirium with different opioids: a systematic review Drugs Aging 34 437-443 https://doi.org/10.1007/s40266-017-0455-9 PMID: 28405945 PMCID: 5427092 
63. Gold J (2017) Prescribing opioids to seniors: It's a balancing act Kaiser Health News

64. Kaye AD, Baluch A, and Scott JT (2010) Pain management in the elderly population: a review Ochsner J 10 179-187

65. Reid MC, et al (2010) Characteristics of older adults receiving opioids in primary care: treatment duration and outcomes Pain Med Malden Mass 11 1063-1071 https://doi.org/10.1111/j.1526-4637.2010.00883.x

66. Papaleontiou M, et al (2010) Outcomes associated with opioid use in the treatment of chronic noncancer pain in older adults: A systematic review and meta-analysis: outcomes associated with opioid use J Am Geriatr Soc 58 1353-1369 https://doi.org/10.1111/j.15325415.2010.02920.x PMID: 20533971 PMCID: 3114446

67. Argoff CE, et al (2018) Rational urine drug monitoring in patients receiving opioids for chronic pain: Consensus recommendations Pain Med Malden Mass 19 97-117 https://doi.org/10.1093/pm/pnx285

68. Guerriero F (2017) Guidance on opioids prescribing for the management of persistent non-cancer pain in older adults World J Clin Cases 5 73-81 https://doi.org/10.12998/wjcc.v5.i3.73 PMID: 28352631 PMCID: 5352962

69. Lavan AH and Gallagher P (2016) Predicting risk of adverse drug reactions in older adults Ther Adv Drug Saf 7 11-22 https://doi. org/10.1177/2042098615615472 PMID: 26834959 PMCID: 4716390

70. Rodrigues MCS and Oliveira C de (2016) Drug-drug interactions and adverse drug reactions in polypharmacy among older adults: an integrative review Rev Lat Am Enfermagem 24 e2800 https://doi.org/10.1590/1518-8345.1316.2800 PMID: 27598380 PMCID: 5016009

71. Gordon DB, et al (2005) American pain society recommendations for improving the quality of acute and cancer pain management: American Pain Society Quality of Care Task Force Arch Intern Med 165 1574-1580 https://doi.org/10.1001/archinte.165.14.1574 PMID: 16043674

72. Chou R, et al (2015) The effectiveness and risks of long-term opioid therapy for chronic pain: a systematic review for a National Institutes of Health Pathways to Prevention Workshop Ann Intern Med 162 276-286 https://doi.org/10.7326/M14-2559 PMID: 25581257

73. Papaleontiou M, et al (2010) Outcomes associated with opioid use in the treatment of chronic noncancer pain in older adults: a systematic review and meta-analysis J Am Geriatr Soc 58 1353-1369 https://doi.org/10.1111/j.1532-5415.2010.02920.x PMID: 20533971 PMCID: 3114446

74. Delgado-Guay MO and Bruera E (2008) Management of pain in the older person with cancer. Part 2: treatment options Oncol Williston Park N 22 148-152

75. AGS Panel on Persistent Pain in Older Persons (2002) The management of persistent pain in older persons J Am Geriatr Soc 50 S205S224 https://doi.org/10.1046/j.1532-5415.50.6s.1.x PMID: 12067390

76. Cavalieri TA (2007) Managing pain in geriatric patients J Am Osteopath Assoc 107 ES10-ES16

77. King S, Forbes K, and Hanks, et al (2011) A systematic review of the use of opioid medication for those with moderate to severe cancer pain and renal impairment: a European Palliative Care Research Collaborative opioid guidelines project Palliat Med 25 525-552 https:// doi.org/10.1177/0269216311406313 PMID: 21708859

78. Kahan M, Mailis-Gagnon A, and Wilson L, et al (2011) Canadian guideline for safe and effective use of opioids for chronic noncancer pain: clinical summary for family physicians. Part 1: general population Can Fam Physician Med Fam Can 57 1257-1266 e407-e418

79. Smith HS and Peppin JF (2014) Toward a systematic approach to opioid rotation J Pain Res [https://doi.org/10.2147/JPR.S55782] PMID: 25378948 PMCID: 4207581

80. Brouquet A, et al (2010) Impaired mobility, ASA status and administration of tramadol are risk factors for postoperative delirium in patients aged 75 years or more after major abdominal surgery Ann Surg 251 759-765 https://doi.org/10.1097/SLA.0b013e3181c1cfc9 PMID: 20224380 
81. Urban D, Cherny N, and Catane R (2010) The management of cancer pain in the elderly Crit Rev Oncol Hematol 73 176-183 https://doi. org/10.1016/j.critrevonc.2009.03.008

82. Kress H G (2009) Clinical update on the pharmacology, efficacy and safety of transdermal buprenorphine Eur J Pain Lond Engl 13 219-230 https://doi.org/10.1016/j.ejpain.2008.04.011

83. Naing C, Yeoh PN, andAung KA (2014) Meta-analysis of efficacy and tolerability of buprenorphine for the relief of cancer pain SpringerPlus 387 https://doi.org/10.1186/2193-1801-3-87

84. Tracy B and Sean Morrison R (2013) Pain management in older adults Clin Ther 35 1659-1668 https://doi.org/10.1016/j.clinthera. 2013.09.026 PMID: 24148553

85. Krantz MJ, Martin J, and Stimmel B, (2009) QTc interval screening in methadone treatment Ann Intern Med 150 387-395 https://doi. org/10.7326/0003-4819-150-6-200903170-00103 PMID: 19153406

86. (2009) American Geriatrics Society Panel on Pharmacological Management of Persistent Pain in Older Persons. Pharmacological management of persistent pain in older persons J Am Geriatr Soc 57 1331-1346 https://doi.org/10.1111/j.1532-5415.2009.02376.x

87. Aiyer R, Barkin RL, and Bhatia A (2017) Treatment of neuropathic pain with venlafaxine: A systematic review Pain Med Malden Mass 18 1999-2012

88. Colvin LA (2019) Chemotherapy-induced peripheral neuropathy: where are we now? Pain 160 Suppl 1 S1-S10 https://doi. org/10.1097/ j.pain.0000000000001540 PMID: 31008843 PMCID: 6499732 